\title{
Targeted Deletion of Vesicular GABA Transporter from Retinal Horizontal Cells Eliminates Feedback Modulation of Photoreceptor Calcium Channels
}

\author{
(D)Arlene A. Hirano, ${ }^{1,2}$ Xue Liu, ${ }^{1}$ Jim Boulter, ${ }^{3}$ James Grove, ${ }^{1}$ Luis Pérez de Sevilla Müller, ${ }^{1}$ \\ Steven Barnes, ${ }^{1,2,4,5 *}$ and Nicholas C. Brecha ${ }^{1,2,6,7 *}$ \\ DOI:http://dx.doi.org/10.1523/ENEURO.0148-15.2016 \\ ${ }^{1}$ Department of Neurobiology, David Geffen School of Medicine, University of California, Los Angeles, Los Angeles, \\ California 90095, ${ }^{2}$ Veterans Administration Greater Los Angeles Healthcare System, Los Angeles, California 90073, \\ ${ }^{3}$ Department of Psychiatry and Biobehavioral Sciences, Hatos Research Center for Neuropharmacology, Semel \\ Institute for Neuroscience and Human Behavior, David Geffen School of Medicine, University of California, Los \\ Angeles, Los Angeles, California 90095, ${ }^{4}$ Department of Physiology and Biophysics, Dalhousie University, Halifax, \\ Nova Scotia B3H 4R2, Canada, ${ }^{5}$ Department of Ophthalmology \& Visual Sciences, Dalhousie University, Halifax, Nova

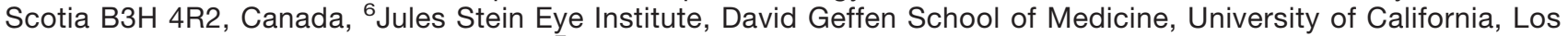 \\ Angeles, Los Angeles, California 90095, ${ }^{7}$ Department of Medicine, David Geffen School of Medicine, University of \\ California, Los Angeles, Los Angeles, California 90095
}

\begin{abstract}
The cellular mechanisms underlying feedback signaling from horizontal cells to photoreceptors, which are important for the formation of receptive field surrounds of early visual neurons, remain unsettled. Mammalian horizontal cells express a complement of synaptic proteins that are necessary and sufficient for calcium-dependent exocytosis of inhibitory neurotransmitters at their contacts with photoreceptor terminals, suggesting that they are capable of releasing GABA via vesicular release. To test whether horizontal cell vesicular release is involved in feedback signaling, we perturbed inhibitory neurotransmission in these cells by targeted deletion of the vesicular GABA transporter (VGAT), the protein responsible for the uptake of inhibitory transmitter by synaptic vesicles. To manipulate horizontal cells selectively, an iCre mouse line with Cre recombinase expression controlled by connexin57 (Cx57) regulatory elements was generated. In Cx57-iCre mouse retina, only horizontal cells expressed Cre protein, and its expression occurred in all retinal regions. After crossing with a VGAT floxfflox mouse line, VGAT was selectively eliminated from horizontal cells, which was confirmed immunohistochemically. Voltage-gated ion channel currents in horizontal cells of Cx57-VGAT ${ }^{-1-}$ mice were the same as Cx57-VGAT ${ }^{+/+}$controls, as were the cell responses to the ionotropic glutamate receptor agonist kainate, but the response to the $\mathrm{GABA}_{\mathrm{A}}$ receptor agonist muscimol in Cx57-VGAT ${ }^{-1}$ mice was larger. In contrast, the feedback inhibition of photoreceptor calcium channels, which in control animals is induced by horizontal cell depolarization, was completely absent in Cx57-VGAT ${ }^{-1}$ mice. The results suggest that vesicular release of GABA from horizontal cells is required for feedback inhibition of photoreceptors.
\end{abstract}

Key words: Ca channels; Cx57-iCre; GABA receptors; inhibitory feedback; retinal horizontal cells; synaptic vesicles

\section{Significance Statement}

Feedback inhibition by horizontal cells regulates the photoreceptor calcium channels responsible for the release of the neurotransmitter glutamate. This feedback inhibition contributes to the formation of the receptive field surrounds of early visual neurons, which is important for contrast sensitivity and color opponency in vision. The cellular mechanisms underlying feedback inhibition are not fully understood. One disputed mechanism for mammalian horizontal cell inhibitory output involves the vesicular release of the inhibitory neurotransmitter GABA. By selectively deleting the transporter that normally loads GABA into vesicles in horizontal cells, we show that horizontal cells lose their ability to modulate photoreceptor calcium signals. These findings implicate a role for the vesicular release of GABA in mediating inhibitory feedback. 


\section{Introduction}

Output from photoreceptors occurs at a synaptic complex composed of the photoreceptor synaptic terminal, bipolar cell dendrites, and horizontal cell endings, forming the initial site of visual information transfer and processing. The ON bipolar dendrites and horizontal cell endings invaginate the photoreceptor terminal. Horizontal cells are known to feed inhibition back onto photoreceptors, but the cellular mechanisms of feedback inhibition in mammals are not fully understood (Thoreson and Mangel, 2012; Liu et al., 2013). We do know that horizontal cell inhibition modulates the presynaptic voltage-gated calcium channels in photoreceptors, which control the release of glutamate from those cells (Thoreson and Mangel, 2012). Evidence exists for several feedback mechanisms at this synapse, including an ephaptic effect and a HEPES-blocked, pH-sensitive mechanism, but a feedback pathway involving vesicular release of an inhibitory neurotransmitter, such as GABA, remains controversial (Thoreson and Mangel, 2012; Liu et al., 2013; Wang et al., 2014; Kemmler et al., 2014).

To address the role of GABA release from mammalian horizontal cells, we created a mouse line in which the vesicular GABA transporter (VGAT) was deleted in horizontal cells, thus preventing them from loading synaptic vesicles with GABA and, hence, knocking out their ability to release GABA by a regulated vesicular mechanism. To do this, we took advantage of the selective expression of the connexin57 (Cx57) gene in retinal horizontal cells (Hombach et al., 2004; Ciolofan et al., 2007) by exchanging the protein-coding region of the $C \times 57$ gene with the "improved" Cre recombinase (iCre) gene (Shimshek et al., 2002), such that Cre expression occurred specifically in horizontal cells. Crosses with floxed VGAT mice (Tong

Received December 2, 2015; accepted January 28, 2016; First published February 28, 2016.

${ }^{1}$ The authors declare no competing financial interests.

${ }^{2}$ Author contributions: A.A.H., J.B., S.B., and N.C.B. designed research; A.A.H., X.L., J.B., J.G., L.P.d.S.M., and S.B. performed research; A.A.H., X.L., J.B., J.G., L.P.d.S.M., S.B., and N.C.B. analyzed data; A.A.H., S.B., and N.C.B. wrote the paper.

${ }^{3}$ This research was supported by National Institutes of Health Grant EY15573 (N.C.B.), UCLA Oppenheimer Seed Grant (A.A.H., J.B., N.C.B.), the Plum Foundation (S.B., N.C.B.), a Veterans Administration Career Scientist Award (N.C.B.), Canadian Institutes of Health Research-Nova Scotia Health Research Foundation Regional Partnership Program Grant MOP10968 (S.B.), and Natural Sciences and Engineering Research Council of Canada Discovery Award 194640 (S.B.).

${ }^{*}$ S.B. and N.C.B. are co-senior authors.

Acknowledgements: We thank Dr. B. Lowell (Beth Israel Deaconess Medical Center, Harvard Medical School) for the VGA flox/flox mice; and Helen Vuong, Alex Solomon, Allen Rodriguez, and Belinda Wong at the University of California, Los Angeles for excellent technical support.

Correspondence should be addressed to Arlene A. Hirano, Department of Neurobiology, David Geffen School of Medicine, University of California, Los Angeles, Los Angeles, CA 90095. E-mail: ahirano@mednet.ucla.edu.

$X$. Liu's present address: Biomaterials and Live Cell Imaging Institute, Chongqing University of Science and Technology, Chongqing 400044, People's Republic of China.

DOI:http://dx.doi.org/10.1523/ENEURO.0148-15.2016

Copyright @ 2016 Hirano et al.

This is an open-access article distributed under the terms of the Creative Commons Attribution 4.0 International, which permits unrestricted use, distribution and reproduction in any medium provided that the original work is properly attributed. et al., 2008) generate mice that have horizontal cells in which VGAT is deleted.

Evidence for GABA receptors and direct actions of GABA on mammalian photoreceptors has been negative or at best equivocal (for review, see Wässle et al., 1998; Thoreson and Mangel, 2012; Kemmler et al., 2014). Renewed motivation to determine whether there is a role for GABA release in feedback inhibition from mammalian horizontal cells comes in part from numerous confirmatory observations in nonmammalian vertebrate retinae (Thoreson and Mangel, 2012), as well as a preponderance of evidence showing that the cellular proteins typically responsible for $\mathrm{Ca}^{2+}$-regulated vesicular release of GABA are present in horizontal cells, including SNAP-25; syntaxin-1a; syntaxin-4; VAMP-1 (vesicle-associated membrane protein 1); GAD; VGAT; and L-, N- and P/Q-type $\mathrm{Ca}^{2+}$ channels in mammalian horizontal cells (Haverkamp et al., 2000; Cueva et al., 2002; Jellali et al., 2002; Johnson et al., 2003; Hirano et al., 2005; 2007; 2011; Sherry et al., 2006; Guo et al., 2009; 2010; Lee and Brecha, 2010; Liu et al., 2013).

In mammalian retina, there is evidence of a mechanism in which GABA release and autoreception signaling by horizontal cells can lead to changes in the $\mathrm{pH}$ of the synaptic cleft. Ionotropic $\mathrm{GABA}_{A}$ receptors $\left(\mathrm{GABA}_{A} \mathrm{Rs}\right)$ and actions have been demonstrated in mouse and rat horizontal cells (Feigenspan and Weiler, 2004; Liu et al., 2013), and it has been proposed that GABA has an indirect role in producing feedback inhibition of photoreceptor Ca channels (Liu et al., 2013). Depolarization of horizontal cells with the ionotropic glutamate receptor (iGluR) agonist kainate activated their voltage-gated $\mathrm{Ca}$ channels, and inhibited photoreceptor calcium signals in rat retinal slices in a HEPES-sensitive manner. Antagonists of $\mathrm{GABA}_{\mathrm{A}}$ receptors blocked this action. The intermediary mechanism of changing cleft $\mathrm{pH}$ is hypothesized to be due to the fact that $\mathrm{GABA}_{\mathrm{A}}$ receptors possess relatively high permeability for bicarbonate $\left(\mathrm{HCO}_{3}^{-}\right)$, as well as chloride $\left(\mathrm{Cl}^{-}\right.$; Bormann et al., 1987), and the resulting flux of $\mathrm{HCO}_{3}^{-}$across the horizontal cell membrane changes the $\mathrm{pH}$ in the synaptic cleft between the horizontal cell and photoreceptor axon terminal. Even small changes of $\mathrm{pH}$ in the cleft modulate the gating of photoreceptor $\mathrm{Ca}$ channels, leading to altered glutamate release from these cells (Barnes et al., 1993). Superfusion with HEPES buffer clamps the extracellular $\mathrm{pH}$ in the cleft, and the prevention of $\mathrm{pH}$ changes blocks inhibitory feedback to photoreceptors (Vessey et al., 2005; Thoreson and Mangel, 2012).

Here we show that the Cre recombinase protein is selectively expressed in horizontal cells of Cx57-iCre mice and, following crosses of Cx57-iCre mice with a VGATflox/flox mouse line, VGAT immunoreactivity is absent from the horizontal cells and their processes in the outer plexiform layer (OPL); and that the intrinsic electrophysiological properties of the Cx57-VGAT ${ }^{-/-}$horizontal cells are normal. Testing the role of horizontal cell-released GABA in photoreceptor calcium channel modulation, we show that the loss of VGAT from horizontal cells eliminates the inhibitory feedback of photoreceptor calcium channels. 


\section{Materials and Methods}

\section{Animal use statement}

Electrophysiological, imaging and immunohistochemical experiments were performed in accordance with the guidelines for the welfare of experimental animals issued by the U.S. Public Health Service Policy on Human Care and Use of Laboratory Animals (2002), the University of California, Los Angeles Chancellor's Animal Research Committee, and the Canadian Council on Animal Care.

\section{Generation of the targeting vector}

The genomic DNA clone of the mouse connexin 57 (Cx57, Gja10) gene was isolated from adult 129/SvJae mouse liver genomic DNA. A Sau3Al restriction endonuclease fragments encoding the Gja10 gene (GenBank accession \#NM_010289) was obtained from a mouse strain 129S4/SvJae genomic DNA library (Stratagene) and subcloned into the vector $\lambda$ FIX II (catalog \#248211, Stratagene). Three genomic clones (MG801, MG806, MG811) containing the Cx57 coding sequence (CDS) were sequenced to determine the physical map. A $8133 \mathrm{bp}$ Nhel restriction endonuclease fragment of MG801 (15,946 bp insert) was subcloned into pBS SK[-] (Stratagene) to produce the $\mathrm{pC} \times 57.1$ construct.

The protein-coding region of the Cx57 gene was replaced precisely by $\mathrm{Ncol}$ and Ndel restriction endonuclease digestion with the improved Cre recombinase gene (where the codon usage has been optimized for expression in mammalian cells; Shimshek et al., 2002). The iCre gene was obtained from pBOB-CAG-iCRE-SD (plasmid ID no. 12336; Addgene). Finally, a positive selection phosphoglycerate kinase (PGK) promoter-neomycin (neo) resistance cassette flanked by two Flp recombinase recognition (FRT) sites was inserted upstream of the iCre gene. The 2FRT-PGK neo cassette was obtained from ploxP-2FRT-PGKneo (originally a gift from S. Fiering, Dartmouth College, Hanover, NH). This construct was subcloned into the targeting vector pKO-Select DT (Lexicon Genetics). This targeting construct pCx57.6 was electroporated into 129S4/SvJae embryonic stem (ES) cells, and homologous recombinants were obtained after gentamicin (G418) selection and Southern blot hybridization analyses. The successfully targeted ES cell clones were injected into mouse blastocysts (embryonic day 3.5), which were then implanted into the uterine horns of pseudopregnant female mice. The resultant chimeric male pups were backcrossed to C57BL/6J female mice, and the progeny were scored for germline transmission of the targeted allele by agouti coat color and genotyping for the iCre transgene. The neo selection cassette was excised by crossing with a FLP1 recombinase mouse (stock \#009086, The Jackson Laboratory; Farley et al., 2000). The Cx57-iCre mice were backcrossed to C57BL/6J mice (males and females; stock \#000664, The Jackson Laboratory).

Routine genotyping of Cx57-iCre mice was performed by using tail biopsy tissue DNA samples (DNeasy Tissue Kit; Qiagen), primers Cx57.11 (5'-AGG AAA GTC TCC
AAC CTG CTG ACT-3') and Cx57.12 (5'-GCC AAT GTG GAT CAG CATTCT CCC-3'), and HotStarTaq DNA Polymerase (Qiagen) as described by the manufacturer. PCR cycle parameters were as follows: $95^{\circ} \mathrm{C}$ for $15 \mathrm{~min}, 55^{\circ} \mathrm{C}$ for $1 \mathrm{~min}$, and $72^{\circ} \mathrm{C}$ for $2 \mathrm{~min}$ for 1 cycle; $95^{\circ} \mathrm{C}$ for $0.5 \mathrm{~min}$, $55^{\circ} \mathrm{C}$ for $1 \mathrm{~min}$, and $72^{\circ} \mathrm{C}$ for $2 \mathrm{~min}$ for 33 cycles; and $95^{\circ} \mathrm{C}$ for $0.5 \mathrm{~min}, 55^{\circ} \mathrm{C}$ for $2.5 \mathrm{~min}$, and $72^{\circ} \mathrm{C}$ for $5 \mathrm{~min}$ for 1 cycle, for a total of 35 cycles. Reaction products were electrophoresed on a $1.5 \%$ agarose/TAE gel, stained with ethidium bromide or GelRed (Biotium) and imaged. The PCR fragment length for the iCre transgene was $600 \mathrm{bp}$.

\section{Mouse lines}

Cx57-iCre mice were crossed with the Cre reporter lines R26-mT/-mG, Ai9(RCL-tdT), or Ai14/RCL-tdT)-D (https://www.jax.org/strain/007576, https://www.jax.org/ strain/007909, and https://www.jax.org/strain/007914, respectively; The Jackson Laboratory), and VGAT flox/flox (gift of Dr. Bradford B. Lowell, Beth Israel Deaconess Medical Center, Harvard Medical School; https://www.jax.org/ strain/012897). Hemizygous Cx57-iCre ${ }^{+1-}::$ tdTomato $^{+1-}$ (Cx57-tdTomato, which are $\mathrm{VGAT}^{+/+}$), Cx57-iCre ${ }^{+/-}:$: $V_{G A T^{+/+}}\left(C \times 57-V G A T^{+/+}\right)$, and Cx57-iCre ${ }^{+/-}: V_{G A T}$ flox/flox (Cx57-VGAT ${ }^{-1-}$ ) mice were used for this study.

\section{Immunohistochemical labeling}

Adult mice of either sex were used for these studies. Following deep anesthesia with 1-3\% isoflurane (IsoFlo; Abbott Laboratories), the eyes were enucleated, and the anterior chamber and lens were removed. The eyecups were immersion fixed in $4 \%(\mathrm{w} / \mathrm{v})$ paraformaldehyde (PFA) or $2 \%$ PLP (2\% PFA, $75 \mathrm{~mm}$ L-lysine, and $10 \mathrm{~mm} \mathrm{Na}$ periodate) in $0.1 \mathrm{M}$ phosphate buffer (PB), $\mathrm{pH} 7.4$, for 15-30 min, cryoprotected in 30\% sucrose and sectioned vertically at 12-14 $\mu \mathrm{m}$ on a cryostat onto gelatin-coated slides. Immunostaining was performed using retinal sections incubated in a blocking solution containing $10 \%$ normal goat serum (NGS), $1 \%$ bovine serum albumin (BSA), $0.5 \%$ Triton $\mathrm{X}-100,0.05 \%$ sodium azide $\left(\mathrm{NaN}_{3}\right)$ in $0.1 \mathrm{M} P B, \mathrm{pH} 7.4$ for $1 \mathrm{~h}$. The primary antibody was diluted in $3 \%$ NGS, $1 \%$ BSA, $0.5 \%$ Triton $\mathrm{X}-100$, and $0.05 \%$ $\mathrm{NaN}_{3}$, in $0.1 \mathrm{M} \mathrm{PB}$, for $12-16 \mathrm{~h}$ at room temperature. The specific immunolabeling was visualized using Alexa Fluor 488-, 568- or 594-conjugated anti-rabbit or mouse secondary antibodies (Invitrogen) at 1:500 dilutions for 40-60 $\mathrm{min}$ at room temperature. The immunostaining was examined on a Zeiss Axioplan2 fluorescence microscope (Carl Zeiss) with a $25 \times 0.8$ numerical aperture (NA) PlanNEOFLUAR objective and a Zeiss Laser Scanning Microscope 510 Meta or 710 confocal microscope equipped with krypton/argon and helium/neon lasers with a 40x C-Apochromat/1.2 NA, C-Apochromat $63 \times / 1.2$ NA corrected water or Plan-Neofluar $63 \times / 1.25$ NA oil objective. Confocal images were acquired with and converted into TIFF files using the Zeiss LSM 510 software. Images were prepared in Photoshop CS4 (Adobe Systems). Antibodies used include a mouse monoclonal against Cre recombinase (1:1000; MAB3120, Millipore) and against calbindin (1:3000; clone CB-955; C9848, Sigma-Aldrich), as well as 
a rabbit polyclonal antibody against calbindin $(1: 10,000$; CB38A; Swant).

\section{Patch-clamp recording from isolated horizontal cells}

Retinae from td-Tomato-labeled Cx57- iCre ${ }^{+/-: . V G A T^{+/+}}$ and $\mathrm{Cx} 57-\mathrm{iCre}^{+/-}:: \mathrm{VGAT}^{-/-}$mice were enzymatically and mechanically dissociated. $\mathrm{I}_{\mathrm{K}}$ and $\mathrm{I}_{\mathrm{Ca}}$ were measured in identified horizontal cells, using standard patch-clamp protocols (Axopatch 200B, pCLAMP version 8.2). Isolated horizontal cells were prepared following incubation of retinae in HBSS (HyClone) containing $18 \mathrm{U} / \mathrm{ml}$ papain and $100 \mathrm{U} / \mathrm{ml}$ DNase I (Worthington Biochemical) at $37^{\circ} \mathrm{C}$ for $40 \mathrm{~min}$. Isolated cells were obtained by gentle trituration after digestion. The cells were kept in DMEM (Life Technologies) with $10 \%$ fetal bovine serum (Life Technologies) in a $\mathrm{CO}_{2}$ incubator at $37^{\circ} \mathrm{C}$. To record voltage-gated $\mathrm{K}^{+}$ currents, isolated horizontal cells were bathed with a solution containing the following (in mM): $125 \mathrm{NaCl}, 3 \mathrm{KCl}$, $2 \mathrm{CaCl}_{2}, 1.25 \mathrm{NaH}_{2} \mathrm{PO}_{4}, 1 \mathrm{MgCl}_{2}, 25 \mathrm{NaHCO}_{3}$, and 10 glucose bubbled continuously with $95 \% \mathrm{O}_{2}, 5 \% \mathrm{CO}_{2}$. The patch pipettes contained the following (in $\mathrm{mm}$ ): $140 \mathrm{KCl}$, $0.1 \mathrm{CaCl}_{2}, 1 \mathrm{EGTA}, 10 \mathrm{HEPES}, 3 \mathrm{Mg}$-ATP, $0.2 \mathrm{Li}-\mathrm{GTP}$, and 8 phosphocreatine, at $\mathrm{pH}$ 7.2. For recordings of voltagegated $\mathrm{Ca}^{2+}$ channel currents, the bath solution was changed to one that had $10 \mathrm{~mm} \mathrm{BaCl}_{2}$ added with no added $\mathrm{CaCl}_{2}$, and the patch pipettes contained the following (in mM): $140 \mathrm{CsCl}, 0.1 \mathrm{CaCl}_{2}, 1$ EGTA, 10 HEPES, $3 \mathrm{Mg}$-ATP, $0.2 \mathrm{Li}-\mathrm{GTP}$, and 8 phosphocreatine, at pH 7.2, adjusted with $\mathrm{CsOH}$. For recordings of muscimol- and kainate-activated currents, the pipette contained the following (in mM): $140 \mathrm{CsCl}, 0.1 \mathrm{CaCl}_{2}, 1$ EGTA, 10 HEPES, and 8 phosphocreatine, at pH 7.2. Room-temperature $\left(21-24^{\circ} \mathrm{C}\right)$ solutions were superfused via a gravity-driven fast-flow system. Patch electrodes with 5-10 M $\Omega$ tip resistance were pulled from borosilicate glass capillary tubes (A-M Systems) using a micropipette puller (Sutter Instrument). The bath reference electrode consisted of an $\mathrm{AgCl}$ wire in a side chamber. Cell voltage was clamped with an Axopatch 200B amplifier (Axon Instruments) using whole-cell capacitance and series resistance compensation. The current signal was filtered at $2 \mathrm{kHz}$ and digitized at $10 \mathrm{kHz}$ with an Axon Digidata 1320A for storage on the hard disk of a computer running pCLAMP version 8.2 acquisition software. Linear leak subtraction was applied to the voltage-gated ion channel recordings at the time of recording or digitally post hoc except when analyzing the conductance changes in response to muscimol and kainate.

\section{$\mathrm{Ca}^{2+}$ imaging in retinal slices}

Young adult mice (1-2 months) of either sex were deeply anesthetized with $1-3 \%$ isoflurane (IsoFlo), the eyes were enucleated, and the anterior portion of an eye, including the lens, was removed. The resulting eyecup was trimmed and a section of retina with scleral backing was placed vitreal side down on a piece of filter $(2 \times 5$ $\mathrm{mm}$, type GS, $0.2 \mu \mathrm{m}$ pores; Millipore). After the retina had adhered to the filter, the sclera was peeled away, and the retina and filter paper were cut into 150-200 $\mu \mathrm{m}$ slices using a tissue chopper (Tissue Slicer; Stoelting Co.) mounted with a razor blade (No. 121-6; Ted Pella), and the slices were rotated $90^{\circ}$ to permit viewing of the retinal layers. Intracellular $\mathrm{Ca}^{2+}$ changes were assessed with the $\mathrm{Ca}^{2+}$-sensitive dye fluo-4 (Invitrogen), which was prepared as a $1 \mathrm{~mm}$ stock solution in DMSO and diluted in mammalian superfusate to a final concentration of $10 \mu \mathrm{M}$. Retinal slices were incubated in fluo- 4 for $1 \mathrm{~h}$ at room temperature in darkness.

Calcium imaging with fluo-4 was performed on retinal slices from Cx57-iCre ${ }^{+/}:$VGAT ${ }^{-1-}$ and Cx57-iCre ${ }^{+/-}$: $V G A T^{+/+}$mice using a Zeiss LSM5 Pascal system with an IR-Achroplan $40 \times / 0.8$ NA water-immersion objective. The $488 \mathrm{~nm}$ laser line of the argon laser provided excitation, and the emission was collected through a $505 \mathrm{~nm}$ longpass filter on a photomultiplier tube. Slices were superfused via a gravity-driven system (ALA Scientific) with a solution containing the following (in $\mathrm{mM}$ ): $125 \mathrm{NaCl}, 3 \mathrm{KCl}$, $2 \mathrm{CaCl}_{2}, 1.25 \mathrm{NaH}_{2} \mathrm{PO}_{4}, 1 \mathrm{MgCl}_{2}, 25 \mathrm{NaHCO}_{3}$, and 10 glucose bubbled continuously with $95 \% \mathrm{O}_{2}, 5 \% \mathrm{CO}_{2}$. To test the changes of activity of voltage-dependent $\mathrm{Ca}^{2+}$ channels in photoreceptors, twin pulses $(30 \mathrm{~s})$ of $30 \mathrm{~mm}$ $\mathrm{K}^{+}$were superfused in the absence and presence of 50 $\mu \mathrm{M}$ kainate (Sigma-Aldrich) or $50 \mu \mathrm{M}$ 2,3-dihydroxy-6-nitro7-sulfonyl-benzo[f]quinoxaline (NBQX; Tocris Bioscience). $\mathrm{NaCl}$ was reduced by $27 \mathrm{~mm}$ to maintain osmolarity. The dose-response relation for the effect of $\left[\mathrm{K}^{+}\right]_{\mathrm{o}}$ on photoreceptor $\left[\mathrm{Ca}^{2+}\right]_{\text {i }}$ was sigmoidal with an $\mathrm{EC}_{50}$ of $17.5 \mathrm{~mm}$ $\mathrm{K}^{+}$, and the value of $30 \mathrm{~mm} \mathrm{~K}^{+}$was chosen as it produced large but nonsaturating responses. Images were acquired at $5 \mathrm{~s}$ intervals. For analysis, regions of interest (ROls) were drawn over the photoreceptor somata, and changes in fluorescence were recorded. The change produced in the presence of the test drug during the second of the paired high-K pulses was compared with the change produced during the first high-K pulse and is shown normalized to the first $\mathrm{K}$ pulse in figure 5 . The common, minor variations of the width of the $\left[\mathrm{Ca}^{2+}\right]_{i}$ response occurred randomly and were not associated with the drug test. Typically, 5-20 ROls were analyzed in each slice, and all experiments were performed on three to five preparations from separate animals.

\section{Data analysis}

All data are reported as the mean \pm SEM, unless otherwise stated. Graphing and statistical analyses were performed using Matlab version 7.6 (MathWorks). Statistical tests were used to determine whether significant differences existed between datasets (specified in Results; Table 1). Normality was assessed quantitatively with a Shapiro-Wilk test and was qualitatively verified with $Q-Q$ plots. $p$ values $<0.05$ were considered to be statistically significant.

\section{Results}

\section{Generation of the conditional knockout of VGAT in mouse horizontal cells}

Due to the structural complexity of the first synapse in the visual system (Haverkamp et al., 2000; Wässle, 2004) as well as the relatively low cell density of horizontal cells across the mammalian retina (Jeon et al., 1998), it has been difficult to manipulate horizontal cells to investigate 
Table 1: Statistical tests

\begin{tabular}{|c|c|c|c|c|}
\hline & Measurement/group & Data structure & Type of test & Confidence interval \\
\hline $\mathrm{a}$ & Kir & Normal & Welch's $t$ test & -257 to $389(\mathrm{pA})$ \\
\hline b & $\mathrm{Kv}$ & Normal & Welch's $t$ test & -1822 to $2328(\mathrm{pA})$ \\
\hline c & Cav & Normal & Welch's $t$ test & -139 to $97(\mathrm{pA})$ \\
\hline d & $V_{1 / 2}$ & Normal & Welch's $t$ test & -14.6 to $22.8(\mathrm{mV})$ \\
\hline e & Muscimol WT & Unknown & Wilcoxon signed rank test & $1.35-0.14(\mathrm{nS})$ \\
\hline$f$ & Muscimol KO & Normal & Paired $t$ test & $4.58-0.85(\mathrm{nS})$ \\
\hline g & Muscimol WT vs KO & Normal & Welch's $t$ test & $0.57-3.60(\mathrm{nS})$ \\
\hline $\mathrm{h}$ & Kainate WT & Normal & Paired $t$ test & $2.19-0.78(\mathrm{nS})$ \\
\hline i & Kainate KO & Normal & Paired $t$ test & $2.39-0.21(\mathrm{nS})$ \\
\hline j & Kainate WT vs KO & Normal & Welch's $t$ test & -1.28 to $0.91(n A)$ \\
\hline k & {$[\mathrm{Ca}]_{\mathrm{i}}$ kainate WT } & Normal & Welch's $t$ test & -28.1 to $-13.5(\%)$ \\
\hline | & {$[\mathrm{Ca}]_{\mathrm{i}} \mathrm{NBQX}$ WT } & Normal & Welch's $t$ test & $8.0-44.6(\%)$ \\
\hline $\mathrm{m}$ & {$[\mathrm{Ca}]_{\mathrm{i}}$ kainate $\mathrm{KO}$} & Unknown & Wilcoxon rank sum test & -8.2 to $24.0(\%)$ \\
\hline$n$ & {$[\mathrm{Ca}]_{\mathrm{i}} \mathrm{NBQX} \mathrm{KO}$} & Normal & Welch's $t$ test & -9.3 to $12.8(\%)$ \\
\hline
\end{tabular}

the molecular mechanisms underlying their neurotransmission. In the mammalian retina, connexin57, a gap junction protein, is expressed solely in horizontal cells (Hombach et al., 2004). We exchanged the coding region of the Cx57 gene (Gja10) with the improved Cre recom- binase gene (iCre) by homologous recombination to generate the Cx57-iCre mouse (Fig. 1A). Consistent with endogenous $\mathrm{Cx} 57$ expression, Cre recombinase protein is selectively expressed in horizontal cells of Cx57-iCre mice, as demonstrated in vertical sections of the Cx57-
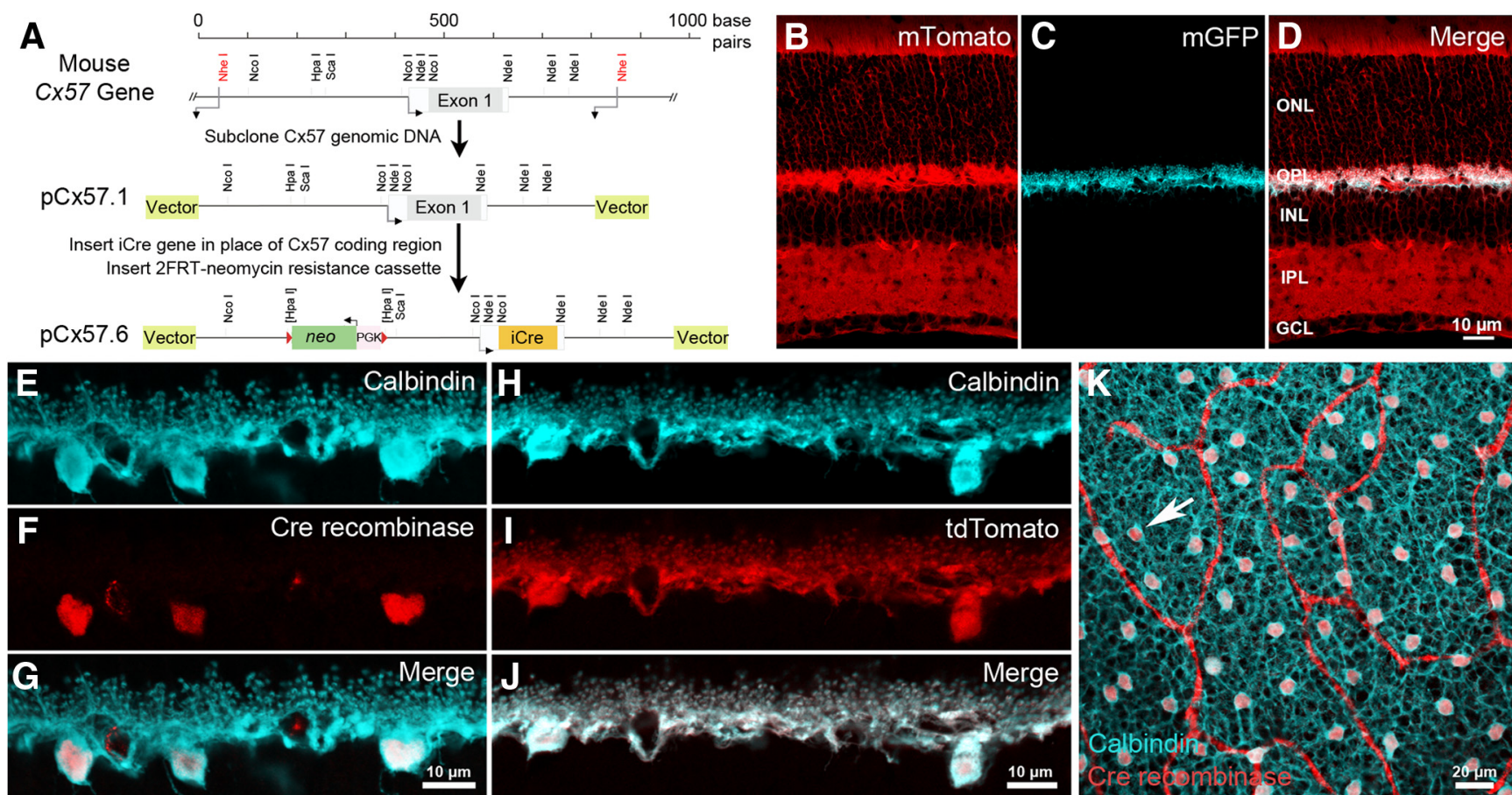

Figure 1. Genetic engineering of $C \times 57-i C r e$ knock-in transgenic mice. $\boldsymbol{A}$, The $\mathrm{Cx} 57$ coding region was removed and replaced with an in-frame, codon-optimized, improved iCre gene to produce the mouse Cx57-iCre targeting construct pCx57.6. $\boldsymbol{B}-\boldsymbol{D}$, In $\mathbf{C} \times 57-i C r e::$ ACTB-mT/mG retinae, non-iCre-expressing cells express membrane-bound tdTomato (mTomato; $\boldsymbol{B}$ ), the expression of membranebound eGFP (mGFP) appears only in horizontal cells $(\boldsymbol{C})$ within the retina, suggesting that recombination occurred specifically in horizontal cells within the retina $(\boldsymbol{D}$, merge). Note that the overall morphology of the retina appeared normal. $\boldsymbol{E}-\boldsymbol{G}$, Calbindin immunoreactivity identified horizontal cells $(\boldsymbol{E}$, blue), and Cre immunolabeling $(\boldsymbol{F}$, red) occurred exclusively in horizontal cell bodies ( $\boldsymbol{G}$, merge). Scale bar, $10 \mu \mathrm{m}$. $\boldsymbol{H}-\boldsymbol{J}, \mathrm{Cx} 57$-iCre crossed with a Cre-dependent reporter line (Ai14, R26R-tdTomato) produced tdTomato expression $(\boldsymbol{I}$, red) in horizontal cells $(\boldsymbol{H})$ overlapping perfectly with calbindin immunolabeling $(\boldsymbol{J}$, white). Scale bar, $10 \mu \mathrm{m}$. $\boldsymbol{K}$, Cre expression occurred in horizontal cells in all regions of the retina. Confocal micrograph of a whole-mount retina from a homozygous Cx57-iCre mouse labeled with antibodies to calbindin (blue) and Cre recombinase (red). Arrow points to a horizontal cell body containing Cre. Red looping bands are nonspecific labeling of blood vessels by the $2^{\circ}$ antibody. Projection of four confocal images; $z$-steps $=0.5 \mu \mathrm{m}$. Scale bar, $20 \mu \mathrm{m}$. ONL, outer nuclear layer; OPL, outer plexiform layer; INL, inner nuclear layer; IPL, inner plexiform layer; GCL, ganglion cell layer. 
A
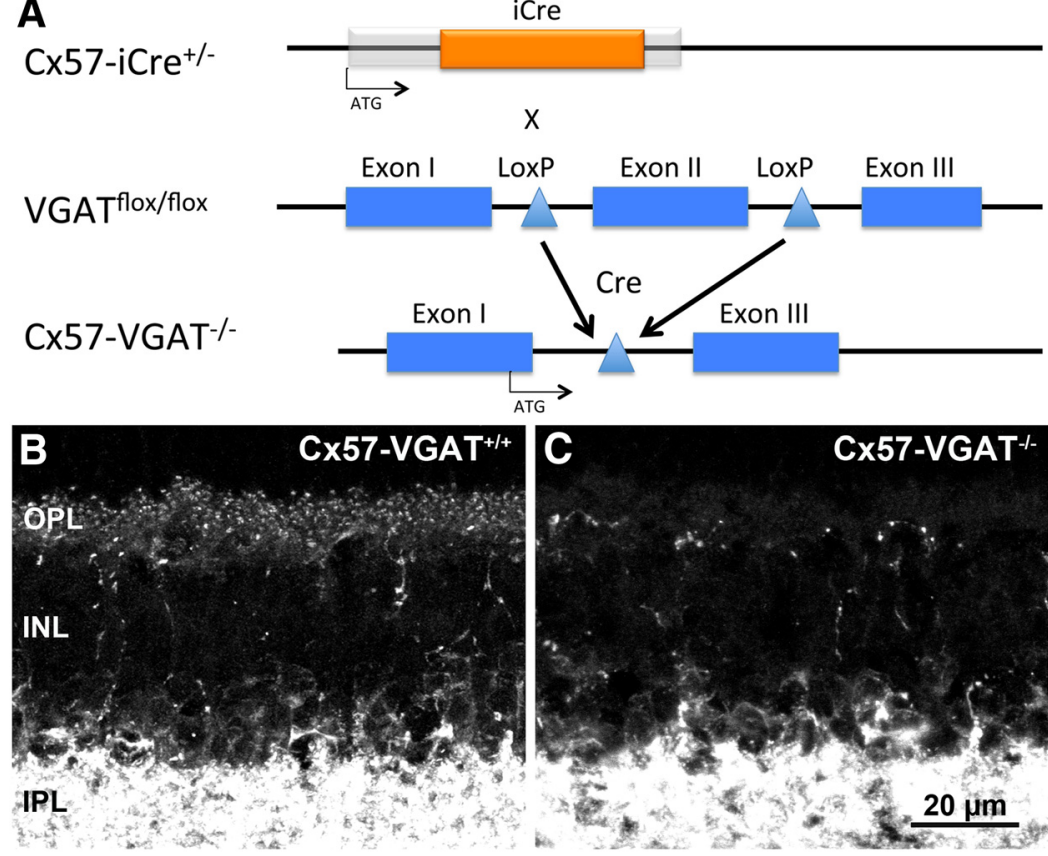

Figure 2. Targeted knockout of VGAT from horizontal cells in Cx57-VGAT ${ }^{-1-}$ retinae. A, Crosses of Cx57-iCre ${ }^{+/-}$and VGATflox/flox mouse lines resulted in a conditional knockout of VGAT in horizontal cells in Cx57-VGAT ${ }^{-1-}$ retinae. $\boldsymbol{B}$, Vertical section of a Cx57-VGAT ${ }^{+/+}$mouse immunolabeled for VGAT in the OPL and IPL. C, VGAT immunolabeling in Cx57-VGAT ${ }^{-1-}$ retinae is missing from horizontal cell tips, but remains unchanged in the IPL. The remaining VGAT-immunoreactive fibers and puncta in the OPL likely correspond to processes of GABAergic interplexiform cells. Note that both $\boldsymbol{B}$ and $\boldsymbol{C}$ show these labeled fibers and puncta. The overall morphology of the retina is unchanged. INL, Inner nuclear layer. Projection of 12 optical sections, $z$-steps $=0.5 \mu \mathrm{m}$. Scale bar, $20 \mu \mathrm{m}$.

iCre retina by the double immunolabeling of $C \times 57-i C r e$ mouse retina with antibodies to Cre and calbindin, a marker for horizontal cells (Fig. 1E-G; Röhrenbeck et al., 1987; Haverkamp and Wässle, 2000; Hirano et al., 2011). The calbindin immunolabeling fills the entirety of the horizontal cell, including the soma, processes and the endings that insert into the photoreceptor triad synapse. Cre immunoreactivity is observed within the cell body, as predicted, because of a nuclear localization signal; further, the Cre-immunoreactive cells were present in all areas of the retina (Fig. $1 \mathrm{~K}$ ). To demonstrate that the iCre protein was capable of mediating recombination, the Cx57-iCre line was crossed with the Cre-reporter line (R26R-mT/mG, The Jackson Laboratory; https://www.jax. org/strain/007576), where cells express membranebound tdTomato fluorescent protein, except in Creexpressing cells. In these cells, the tdTomato gene is deleted by the Cre recombinase and the membranebound enhanced green fluorescent protein (eGFP) is expressed instead (Fig. 1B-D). In the Cx57-iCre::R26R$m T / m G$ retina, the eGFP is confined to the plasma membrane of horizontal cells in the OPL (Fig. 1C). When Cre-reporter lines, such as Aig(RCL-tdT) (The Jackson Laboratory; https://www.jax.org/strain/007909) or Ai14 (RCL-tdT)-D (The Jackson Laboratory; https://www.jax. org/strain/007914; Madisen et al., 2010) are used, strong fluorescent protein expression is observed in horizontal cells. In the Cx57-iCre::Ai14 retina, tdTomato reporter expression was observed in horizontal cells (Fig. $1 H-J$ ).
Light microscopic analyses of the retinae from these crosses indicated that Cre successfully mediated recombination in horizontal cells, and that the overall retinal morphology was maintained.

\section{VGAT is selectively eliminated from horizontal cells} in the retina

To test whether vesicular GABA release from horizontal cells participates in inhibitory feedback to photoreceptors, we conditionally eliminated VGAT expression in horizontal cells. The Cx57-iCre mouse line was crossed with a VGAT flox/flox mouse line (The Jackson Laboratory; https://www.jax.org/strain/012897), in which exon 2 of the VGAT gene is flanked by loxP sites and is excised upon recombination (Fig. 2A; Tong et al., 2008). Immunolabeling for VGAT in the retinae of $C \times 57-i C r e^{+/-}: . V G A T^{+/+}$ (Cx57-VGAT ${ }^{+/+}$) and Cx57-iCre ${ }^{+/}::$VGATflox/flox (Cx57$V G A T^{-1-}$ ) mice, shown in Figure 2, $B$ and $C$, respectively, revealed that VGAT immunoreactivity was absent from the horizontal cells and their processes in the OPL in the Cx57-VGAT ${ }^{-1-}$ retina. Whereas in both, the amacrine cells in the inner retina and their processes in the inner plexiform layer maintained high levels of VGAT immunoreactivity. Some VGAT-specific staining remained in the OPL of Cx57-VGAT ${ }^{-1-}$ mice, which is attributable to processes of GABA-releasing interplexiform cells (Witkovsky et al., 2008; Dedek et al., 2009). These processes can be discerned in the control animals as well (Fig. 2B,C). There 
A
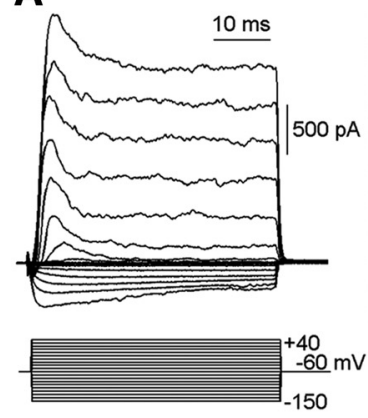

E

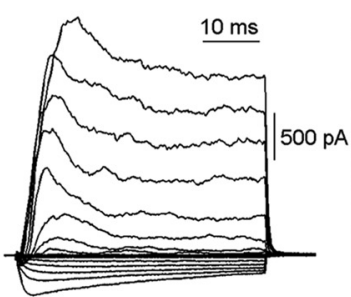

B

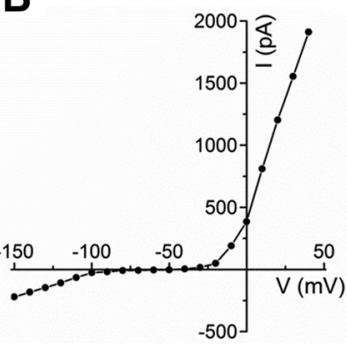

$-500$
C

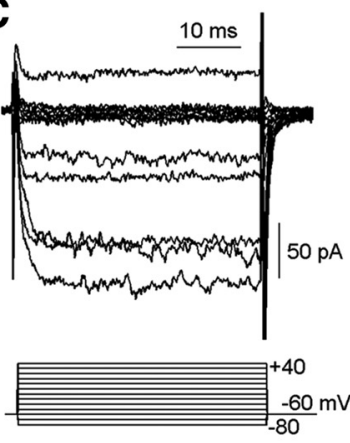

G

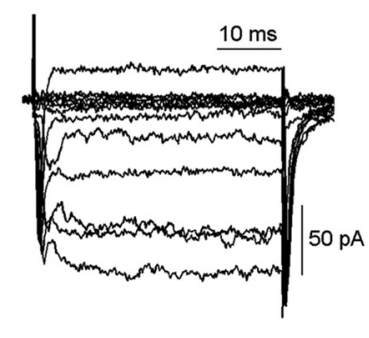

D

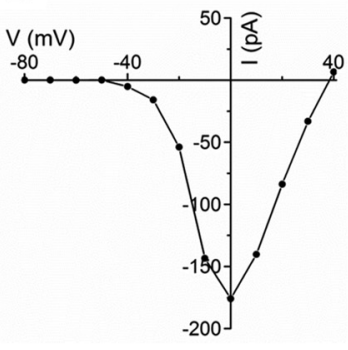

H

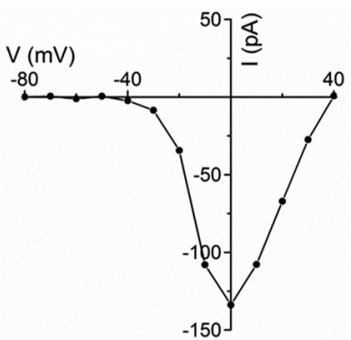

Figure 3. Voltage-gated $\mathrm{K}^{+}$and $\mathrm{Ca}^{2+}$ channel currents remain normal in horizontal cells from Cx57-VGAT ${ }^{-1-}$ retinae. $\boldsymbol{A}-\boldsymbol{H}$, Whole-cell voltage-clamp recordings from isolated horizontal cells from Cx57-tdTomato VGAT $T^{+/+}(\boldsymbol{A}-\boldsymbol{D})$ and $C \times 57-V G A T^{-1-}(\boldsymbol{E}-\boldsymbol{H})$ mice show that the membrane currents of horizontal cells are unaffected by the deletion of VGAT. Examples of inward and outward $\mathrm{K}^{+}$currents from normal $(\boldsymbol{A})$ and VGAT knock-out $(\boldsymbol{E})$ horizontal cells are similar, and their peak current-voltage $(I-V)$ relations $(\boldsymbol{B}, \boldsymbol{F})$ are comparable. Ca channel currents recorded with $10 \mathrm{~mm} \mathrm{Ba}^{2+}$ in wild-type $(\boldsymbol{C})$ and knockout $(\boldsymbol{G})$ are similar, with indistinguishable $I-V$ relations $(\boldsymbol{D}, \boldsymbol{H})$.

was no obvious alteration in the overall morphology and thickness of the synaptic and cellular layers of the retina.

\section{Electrophysiological properties of $V_{G A T^{-\prime-}}$ horizontal cells are unchanged from those recorded in $\mathrm{VGAT}^{+/+}$mice}

With the goal of evaluating the functional capacities of horizontal cells of $C \times 57-V G A T^{-1-}$ mice, we characterized their intrinsic properties to test for possible differences that could affect feedback. We assessed inward rectifier $\mathrm{K}^{+}$currents, outwardly rectifying $\mathrm{K}^{+}$currents, and inward $\mathrm{Ca}^{2+}$ channel currents using whole-cell voltage clamp of isolated horizontal cells identified by their expression of tdTomato. Figure 3 compares whole-cell membrane currents recorded from control, Cx57-tdTomato-VGAT ${ }^{+/+}$, and Cx57-VGAT ${ }^{-1-}$ knockout mice, and they showed no discernible difference. Inward rectifier $\mathrm{K}$ channels (Tachibana, 1983) and outwardly rectifying K currents (Feigenspan et al., 2009) were the same in $V G A T^{+/+}$and $V G A T^{-1-}$ mice, as judged by the peak current amplitudes and the kinetics of the voltage-dependent activation. Inward rectifier $\mathrm{K}^{+}$(Kir) currents had a peak magnitude of $-354 \pm 123 \mathrm{pA}$ at $-150 \mathrm{mV}$ in control $V G A T^{+/+}$mice $(n=9)$ and an insignificantly different $-288 \pm 87 \mathrm{pA}$ in $V G A T^{-1-}$ mice $\left(p=0.67 ; n=8\right.$; Welch's $t$ test $\left.^{\mathrm{a}}\right)$. Outwardly rectifying $\mathrm{K}^{+}(\mathrm{Kv})$ currents in $V G A T^{+/+}$mice had a peak magnitude of $2018 \pm 845 \mathrm{pA}$ at $+40 \mathrm{mV}(n=9)$, while in $V G A T^{-1-}$ mice, the peak amplitude was not significantly different at $1765 \pm 418 \mathrm{pA}(p=0.79 ; n=9$;
Welch's $t$ test $^{\mathrm{b}}$ ). Amplitude and kinetics of $\mathrm{Ca}$ channel (Cav) currents in horizontal cells (Schubert et al., 2006) carried by $\mathrm{Ba}^{2+}$ were indistinguishable between $V G A T^{+/+}$ and $V G A T^{-1-}$ mice. For control mice, Ca channel currents had a peak amplitude of $-151 \pm 42 \mathrm{pA}$ at $-10 \mathrm{mV}(n=$ 20 ), with a membrane potential for half activation $\left(V_{1 / 2}\right)$ of $-13.0 \pm 6.2 \mathrm{mV}$, while in $V G A T^{-1-}$ mice the peak amplitude, occurring at the same membrane potential, was $-130 \pm 39 \mathrm{pA}\left(p=0.72 ; n=10 ;\right.$ Welch's $t$ test $\left.^{\mathrm{C}}\right)$, and the $V_{1 / 2}$ was $-17.1 \pm 6.6 \mathrm{mV}(p=0.66 ; n=10$; Welch's $t$ test $^{\mathrm{d}}$ ), with neither parameter showing a significant difference. These results indicate that the voltage-gated ion channels of horizontal cells from VGAT ${ }^{-1-}$ mice have normal properties and that the cells should be capable of producing wild-type membrane potential responses to stimulation.

The feedback mechanism recently proposed to operate in the rat retina involves horizontal cell release of GABA onto themselves in an autocrine manner, and our experimental paradigm for testing this relies on the depolarization of the horizontal cells with the iGluR agonist, kainate, and competent GABA $A_{A}$ receptors (Liu et al., 2013). Therefore, the functionality of GABA and glutamate receptors was compared in Cx57-tdTomato-VGAT ${ }^{+/+}$and Cx57$V G A T^{-1-}$ mice to assess possible changes to these horizontal cell neurotransmitter receptors. Application of the $\mathrm{GABA}_{\mathrm{A}}$ receptor agonist $50 \mu \mathrm{M}$ muscimol in isolated horizontal cells from both Cx57-VGAT $T^{+/+}$and Cx57$V G A T^{-1-}$ produces slope conductance increases (Fig. 

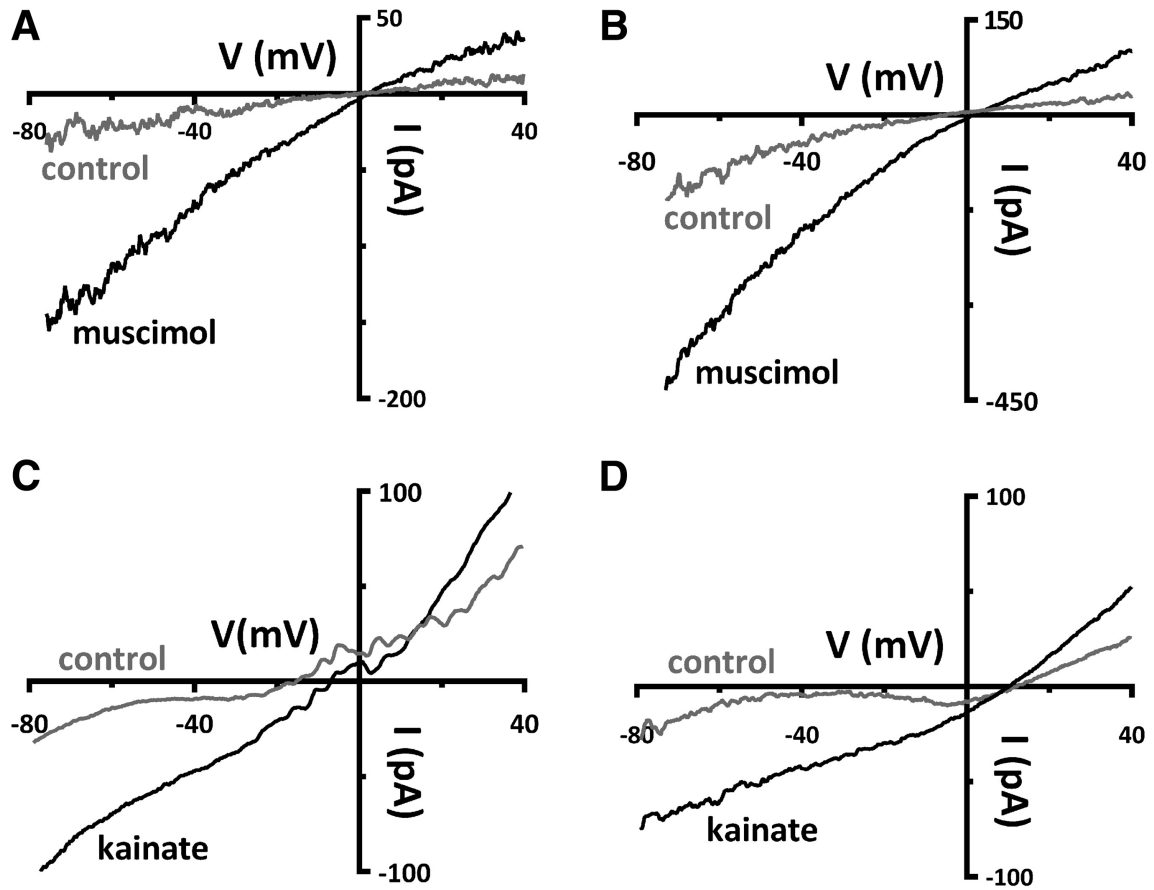

Figure 4. Excitatory and inhibitory ligand-gated currents are present in horizontal cells from Cx57-VGAT ${ }^{-1-}$ retinae. $\boldsymbol{A}, \boldsymbol{B}$, Whole-cell voltage-clamp recordings, with $\mathrm{CsCl}$-filled pipettes, of isolated horizontal cells from control Cx57-tdTomato VGAT ${ }^{+/+}(\boldsymbol{A})$ and knock-out Cx57-VGAT ${ }^{-1-}$ mice (B) show that ionotropic GABA receptors in horizontal cells are unaffected by the deletion of VGAT. Currents in response to ramps ( -80 to $+40 \mathrm{mV}, 240 \mathrm{~ms}$ ) are shown before (control) and during bath superfusion of $50 \mu \mathrm{M}$ muscimol, a GABA ${ }_{A} R$ agonist. The slope conductance of the current-voltage $(I-V)$ relations increased in both in $C \times 57-V G A T^{+1+}$ and $C x 57-$ $V G A T^{-1-}$ mice during muscimol superfusion (values summarized in text), although the muscimol-induced conductance was larger in the knock out animals. $\boldsymbol{C}, \boldsymbol{D}$, Glutamate receptor function was tested with $50 \mu \mathrm{m}$ kainate superfused on $C \times 57-V G A T^{+/+}(\boldsymbol{C})$ and Cx57-VGAT ${ }^{-1-}$ horizontal cells $(\boldsymbol{D})$. Currents in response to ramps are shown before and during bath superfusion of $50 \mu \mathrm{M}$ kainate. The increases in slope conductance of the $I-V$ relations during kainate superfusion were not significantly different in horizontal cells from $V G A T^{+/+}$and $V G A T^{-/-}$mice (values summarized in text).

$4 A, B)$. When muscimol (50 $\mu \mathrm{M})$ was superfused, the normalized conductance increased significantly by $0.55 \pm$ $0.20 \mathrm{nS}$ in $\mathrm{VGAT}^{+/+}$mice $(p=0.03 ; n=6$; Wilcoxon signed rank test $\left.{ }^{\mathrm{e}}\right)$. In $V G A T^{-1-}$ mice, the muscimolinduced increase in conductance was $2.72 \pm 0.43 \mathrm{nS}(p=$ $0.02 ; n=3$; paired $t$ test $\left.^{\dagger}\right)$. In $V G A T^{+/+}$mice, five of six cells recovered to $103 \% \pm 41 \%$ after washout of muscimol, while in $V G A T^{-1-}$ mice two of three cells recovered to $100 \% \pm 1 \%$ in washout (with one cell in each condition not recorded in washout). The increase in conductance induced by muscimol was larger in the $V G A T^{-1-}$ mice than in the VGAT $T^{+/+}$mice ( $p=0.021$; Welch's $t$ test $\left.^{\mathrm{g}}\right)$. Glutamate receptor function was tested with $50 \mu \mathrm{M}$ kainate, a mixed AMPA and kainate receptor agonist, on isolated horizontal cells, and control and VGAT ${ }^{-1-}$ mice responded with similar increases in slope conductance (Fig. $4 C, D)$. Superfusion with kainate $(50 \mu \mathrm{M})$ increased the conductance by $1.49 \pm 0.22 \mathrm{nS}$ in $V G A T^{+/+}$mice $(p=$ $0.007 ; n=4$; paired $t$ test $^{\mathrm{h}}$ ), while in $V G A T^{-/-}$mice the kainate-induced increase was $1.30 \pm 0.39 \mathrm{nS}(p=0.03$; $n=5$; paired $t$ test'). In $V G A T^{+/+}$mice, three of four cells recovered after washout (to $110 \% \pm 3 \%$ ), whereas in VGAT ${ }^{-1-}$ mice, three of five cells recovered to $112 \% \pm$ $3 \%$ in washout (with one and two cells in each condition, respectively, not recorded in washout). The increase in conductance induced by kainate was not significantly different between the $V G A T^{+/+}$and $V G A T^{-/-}$groups $(p=$ 0.69; Welch's $t$ test $\left.{ }^{j}\right)$. These data show that horizontal cells in $V G A T^{-1-}$ mice are capable of responding normally to GABA and glutamate receptor agonists.

\section{Inhibitory feedback to photoreceptors is absent in VGAT ${ }^{-/-}$mice}

With normal electrophysiological properties established for the $V G A T^{-1-}$ mice, in particular their responses to the neurotransmitters GABA and glutamate, we next assessed output from horizontal cells using calcium imaging in living retinal slices to test the role of VGAT expression in horizontal cells in feedback onto photoreceptors. This assay has been used in retinae from zebrafish (Vessey et al., 2005), salamander (Cadetti and Thoreson, 2006; Thoreson et al., 2008; Babai and Thoreson, 2009), mouse (Babai and Thoreson, 2009), and rat (Liu et al., 2013), and permits analysis of the inhibitory effects of horizontal cell depolarization on the voltage-gated $\mathrm{Ca}$ channels of rod and cone photoreceptors. The assay uses the iGluR agonist kainate and the iGluR antagonist NBQX to depolarize or hyperpolarize horizontal cells, respectively, in conjunction with brief applications of $30 \mathrm{~mm}$ potassium that depolarize mouse rods from -54 to $-35 \mathrm{mV}$ and rat rods from -53 to $-41 \mathrm{mV}$, and elicit $\mathrm{Ca}$ influx into the photoreceptors (Babai and Thoreson, 2009; Liu et al., 
2013). Kainate, which has a typical $E_{50}$ in the range of 120-160 $\mu \mathrm{M}$ at AMPA receptors (Huettner, 1990; Patneau and Mayer, 1991), has been reported to depolarize isolated rat horizontal cells by $22 \mathrm{mV}(50 \mu \mathrm{M}$; Liu et al., 2013), salamander horizontal cells in retinal slices by $31 \mathrm{mV}(1$ $\mathrm{mm}$ puffs), and isolated turtle horizontal cells by $\sim 50 \mathrm{mV}$ (20 $\mu \mathrm{M}$; Hirasawa and Kaneko, 2003), whereas 6,7dinitroquinoxaline-2,3-dione (DNQX; $100 \mu \mathrm{M}$ puffs), an iGluR antagonist having an $\mathrm{EC}_{50}$ of $\sim 10 \mu \mathrm{M}$ (Honoré et al., 1988), hyperpolarizes the cells by $12 \mathrm{mV}$ (Babai and Thoreson, 2009). The iGluR agonists and antagonists have no direct effect on photoreceptors (Thoreson et al., 2008; Babai and Thoreson, 2009; Liu et al., 2013; Kemmler et al., 2014). Kainate increases feedback inhibition of $\mathrm{Ca}$ channels in photoreceptors from zebrafish, salamander, mouse, and rat, reducing their depolarization-evoked calcium signals; whereas NBQX or DNQX decreases the feedback inhibition of photoreceptors, increasing their depolarization-evoked calcium signals (Hirasawa and Kaneko, 2003; Vessey et al., 2005; Cadetti and Thoreson,
2006; Thoreson et al., 2008; Babai and Thoreson, 2009; Fahrenfort et al., 2009; Liu et al., 2013).

Pharmacological modulation of horizontal cell membrane potential with NBQX and kainate, which shortcircuits the inhibitory feedback loop between horizontal cells and photoreceptors, partly mimics the effects of slow timescale, bright full-field illumination, and full-field darkness, respectively. Our use of fluorescence-based calcium imaging with a confocal microscope, which entails bright stimulation with blue light to drive the fluorescent signals that report calcium levels, limited the use of darkness itself to increase the inhibition of the photoreceptors. It may be fruitful to further study these actions of horizontal cell membrane polarization using more natural stimuli. The controlled depolarization of photoreceptors with $30 \mathrm{mM} \mathrm{K}^{+}$stimulates $\left[\mathrm{Ca}^{2+}\right]_{\mathrm{i}}$ increases providing strong signal-to-noise ratios, as shown in the numerous previous studies in which this technique has been used.

In control Cx57-VGAT ${ }^{+/+}$mice, $30 \mathrm{~mm} \mathrm{~K}^{+}$depolarizationinduced photoreceptor $\left[\mathrm{Ca}^{2+}\right]_{\mathrm{i}}$ signals were reduced by

A Control B VGAT ${ }^{-1}$ C Control D VGAT ${ }^{-1-}$
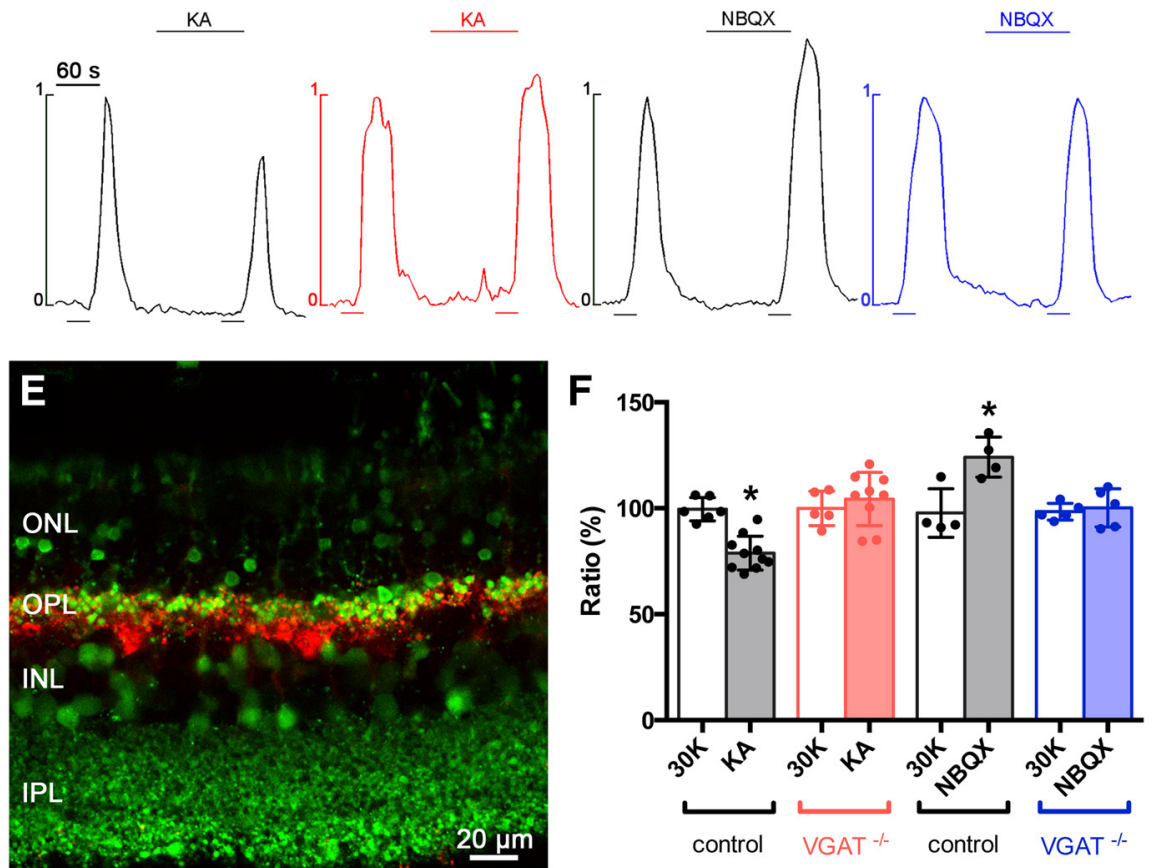

Figure 5. Deletion of VGAT in horizontal cells results in the loss of inhibitory feedback modulation of photoreceptor [Ca $\left.{ }^{2+}\right]_{\mathrm{i}}$. Feedback inhibition to photoreceptors was eliminated in retinal slices from Cx57-VGAT ${ }^{-/-}$mice. A, In Cx57-VGAT ${ }^{+/+}$mice, $50 \mu \mathrm{M}$ kainate (KA), which depolarizes horizontal cells, inhibited high $\left[\mathrm{K}^{+}\right]$-evoked calcium signals in photoreceptors (timing shown in bars below traces), suggesting an increase in inhibitory feedback. The high $\left[\mathrm{K}^{+}\right]$stimulus was always superfused for $30 \mathrm{~s}$, the timing of which is shown by the horizontal bar below the traces. C, $50 \mu \mathrm{m}$ NBQX, which hyperpolarizes horizontal cells, enhanced calcium signals in photoreceptors, suggesting a decrease in inhibitory feedback. $\boldsymbol{B}, \boldsymbol{D}$, In $C x 57-V G A T^{-1-}$ retinal slices, kainate did not increase inhibitory feedback to photoreceptors $(\boldsymbol{B})$, and NBQX did not reduce inhibitory feedback $(\boldsymbol{D})$. Fluorescence traces are shown normalized to the first of each paired response to high $\left[\mathrm{K}^{+}\right]$application. Calibration: $60 \mathrm{~s}$. $\boldsymbol{E}$, Confocal image of a Cx57-tdTomato retinal slice loaded with fluo-4 (green). The expression of tdTomato (red) identifies the horizontal cells within the slice. Photoreceptor cell bodies are in the outer nuclear layer and their axon terminals are in the OPL. $\boldsymbol{F}$, Summary of photoreceptor calcium signal amplitudes in retinal slices from VGAT $T^{+/+}$and VGAT ${ }^{-/-}$mice treated with kainate and NBQX. Graph shows normalized mean values \pm SDs from multiple retinal slices with one data point (filled circle) per slice, each of which was averaged from 5 to 20 individual photoreceptors from three to five different eyes. ONL, Outer nuclear layer; INL, inner nuclear layer. 
$21 \% \pm 3 \%\left(p=0.00003\right.$; Welch's $t$ test $\left.^{k}\right)$ when $50 \mu \mathrm{M}$ kainate was applied and increased by $24 \% \pm 5 \%(p=$ 0.01; Welch's $t$ test') when $50 \mu \mathrm{M}$ NBQX was applied (Fig. $5 A, C$ ), confirming previous findings (Vessey et al., 2005; Cadetti and Thoreson, 2006; Thoreson et al., 2008; Babai and Thoreson, 2009; Fahrenfort et al., 2009; Liu et al., 2013). In contrast, kainate and NBQX in Cx57-VGAT ${ }^{-1-}$ mice failed to produce a change in photoreceptor $\left[\mathrm{Ca}^{2+}\right]_{\mathrm{i}}$ (Fig. 5B,D). In Cx57-VGAT ${ }^{-1-}$ mice, $50 \mu \mathrm{M}$ kainate produced an insignificant increase of the photoreceptor calcium signal during the second $\mathrm{K}^{+}$pulse $(9 \% \pm 6 \%$; $p=0.37$; Wilcoxon rank sum test $\left.{ }^{\mathrm{m}}\right)$, and $50 \mu \mathrm{M}$ NBQX produced no change in the calcium signal $(0 \pm 4 \%$; $p=$ 0.70; Welch's $t$ test $^{\mathrm{n}}$ ). Note that kainate and NBQX did not appear to directly affect the photoreceptor $\left[\mathrm{Ca}^{2+}\right]_{\mathrm{i}}$, prior to the high-K stimulus. Figure $5 F$ summarizes the actions of kainate and NBQX in control and Cx57-VGAT ${ }^{-1-}$ mice. These findings show that the modulation of photoreceptor $\mathrm{Ca}$ channels, the key action underlying horizontal cell feedback inhibition, is eliminated in animals lacking VGAT in their horizontal cells.

\section{Discussion}

The results presented here, achieved by creating a mouse line in which horizontal cells do not express VGAT, the transporter responsible for high-affinity uptake of GABA by synaptic vesicles (McIntire et al. 1997), demonstrate that depletion of VGAT from horizontal cells eliminates inhibitory feedback of photoreceptor $\left[\mathrm{Ca}^{2+}\right]_{i}$ levels. Even though horizontal cells have long been known to send inhibitory signals to photoreceptors and bipolar cells, the mechanisms that underlie this neurotransmission remain unresolved (Thoreson and Mangel, 2012). Pharmacological tests of the physiological role of GABA in the outer retina have provided contradictory results (turtle, Thoreson and Burkhardt, 1990; primate, Verweij et al., 2003; McMahon et al., 2004; Davenport et al., 2008; for review, see Thoreson and Mangel, 2012; rat, Liu et al., 2013; mouse, Pattnaik et al., 2000; Kemmler et al., 2014). In patch clamped turtle cones, GABA-activated $\mathrm{Cl}^{-}$currents were detected only when the GABA receptor-potentiating drug pentobarbital was added (Tatsukawa et al., 2005). In the present experiments, which were performed in mouse retina, no potentiating drugs were added. This suggests that, under the conditions of our recordings, the mouse retina releases enough GABA or expresses sufficient GABA receptors for the slow physiological responses we detected. In cold-blooded vertebrates, a plasma membrane GABA transporter-1 (GAT-1) has been shown to release GABA in an electrogenic, Ca-independent manner (Schwartz, 2002). However, mammalian horizontal cells do not express GATs (Johnson et al., 1996; Guo et al., 2009), suggesting that a different mechanism must be used. It is known that feedback inhibition to photoreceptors depends on horizontal cell membrane potential, but the mechanism by which GABA release might produce this modulation in mammalian retinae has remained unsettled (Thoreson and Mangel, 2012). By generating the Cx57-iCre transgenic mouse line, specific genetic manip- ulation of horizontal cells enabled this study of horizontal cell function in the absence of VGAT on synaptic vesicles.

\section{Validation of Cx57-iCre mouse}

Horizontal cell bodies are sparsely distributed, making up only a small percentage of the total number of retinal cells, yet they innervate all photoreceptor terminals (Wässle, 2004). The photoreceptor synapse is complex, consisting of ON bipolar cell dendrites (approximately seven morphological subtypes of cone bipolar cells and one rod bipolar cell) and horizontal cell endings that invaginate the photoreceptor terminal, and approximately five OFF cone bipolar cell types that form synapses at the base of the cone pedicle (Haverkamp et al., 2000; Wässle et al., 2009). The dendrites of type $B$ horizontal cells, the only morphological type in the mouse retina (Peichl and González-Soriano, 1994), innervate cone terminals, whereas the axon terminal system innervates rod terminals (Wässle, 2004). Nevertheless, similar HEPESsensitive, $\mathrm{pH}$-dependent feedback inhibition of photoreceptor calcium channels appears to occur at rod and cone terminals (Thoreson et al., 2008; Babai and Thoreson, 2009; Thoreson and Mangel, 2012)

The successful development of a Cx57-iCre mouse line allowed us to take advantage of Cre-loxP technology (Sauer, 1998) and a growing number of Cre-dependent lines and viral vectors to selectively manipulate proteins and cellular pathways in horizontal cells. For example, crosses with Cre-reporter lines, such as Ai14(RCL-tdT)-D, produced strong expression of fluorescent proteins in horizontal cells, permitting their targeting for electrophysiological and immunohistochemical analysis. Recently, GluR4 was deleted in mouse horizontal cells using a strategy broadly similar to that used here (Ströh et al., 2013).

The selective loss of VGAT from the horizontal cells did not produce gross alterations in retinal morphology. The light microscopic analysis indicated that the horizontal cell morphology and the OPL appeared unchanged in the Cx57-iCre transgenic and the Cx57-VGAT ${ }^{-1-}$ mouse lines. Similarly, retinal morphology of $C \times 57^{+/ l a c z}$ heterozygotes and $\mathrm{C} \times 57^{\mathrm{lacZ} / \mathrm{lac} Z}$ nulls was reported to be normal (Shelley et al., 2006; Janssen-Bienhold et al., 2009), as was the synaptic morphology between photoreceptors and horizontal cells (Shelley et al., 2006). Recently, another connexin isoform (Cx50), which couples axon terminals of mouse horizontal cells, was reported (Dorgau et al., 2015).

The functional characterization in this article used hemizygous $C \times 57-i C r e$ mice, meaning that there was a copy of each gene, and $\mathrm{Cx} 57$ (and iCre) protein in all horizontal cells. Horizontal cells in heterozygous $\mathrm{C} \times 57^{+/-}$mice show reduced tracer coupling, which is reflective of lower Cx57 protein levels (Hombach et al., 2004). However, the homozygous deletion of $\mathrm{C} \times 57$ (i.e., a Cx57 knockout), which appeared to eliminate tracer coupling (Hombach et al., 2004), did not disrupt spatial tuning at the ganglion cell level or in behavioral assays (Dedek et al., 2008). Notably, the slow rollback of the photoreceptor light response, considered to arise from feedback, is intact in Cx57 
knockout mice, indicating that $\mathrm{Cx} 57$ is not essential for the feedback inhibition of photoreceptors (Shelley et al., 2006).

The intrinsic electrophysiological properties of the Cx57-VGAT ${ }^{-1-}$ horizontal cells appear unchanged from those isolated from wild-type C57BL/6 mice (Schubert et al., 2006; Feigenspan et al., 2009) and Cx57-iCre ${ }^{+/-}$ tdTomato-VGAT ${ }^{+/+}$retinae. Significantly, the horizontal cell calcium currents that trigger vesicular release showed amplitudes, kinetics, and current-voltage relations in Cx57-VGAT ${ }^{-1-}$ mice that were similar to those in Cx57$V G A T^{+/+}$mice. There was also no change in photoreceptor calcium influx following depolarization with control high $\mathrm{K}^{+}$in the two transgenic mouse lines, and the voltage-gated $\mathrm{K}$ channels in Cx57-VGAT $T^{+/+}$and $\mathrm{Cx} 57-$ $V G A T^{-\prime-}$ mice were the same. The response of isolated horizontal cells to the iGluR agonist kainate and to the $\mathrm{GABA}_{\mathrm{A}} \mathrm{R}$ agonist muscimol was similar in Cx57-VGAT ${ }^{+/+}$ and Cx57-VGAT ${ }^{-1-}$ animals, although the muscimolinduced conductance was larger in the knock out animals. Thus, the loss of feedback inhibition to photoreceptors following VGAT knockout in horizontal cells is not due to altered properties of calcium or potassium channel currents in horizontal cells, nor is it due to a loss of expression of iGluRs or $\mathrm{GABA}_{\mathrm{A}} \mathrm{Rs}$, which are intrinsic to these cells.

\section{Inhibitory feedback to photoreceptors is absent in the Cx57-VGAT ${ }^{-1-}$ retina}

In wild-type retinae, the depolarization of horizontal cells by kainate or positive current injection produces $\mathrm{Ca}$ channel inhibition in photoreceptors due to increased inhibitory feedback from horizontal cells (Thoreson and Mangel, 2012). Likewise, when horizontal cells are hyperpolarized by NBQX or negative current injection, the increase in photoreceptor $\mathrm{Ca}_{\mathrm{i}}$ indicates that inhibitory feedback is reduced. Feedback inhibition by horizontal cells results in modulation of the photoreceptor calcium current and, consequently, of the release of photoreceptor transmitter (Thoreson and Mangel, 2012).

The manipulation of horizontal cell membrane potential in wild-type retinae with kainate and NBQX generates reproducible modulations of high $\mathrm{K}^{+}$-evoked $\mathrm{Ca}^{2+}$ signals in photoreceptors in many cold-blooded vertebrates and mammals, including mice, as we show here (Hirasawa and Kaneko, 2003; Vessey et al., 2005; Cadetti and Thoreson, 2006; Thoreson et al., 2008; Babai and Thoreson, 2009; Fahrenfort et al., 2009; Liu et al., 2013). In contrast, in Cx57-VGAT ${ }^{-1-}$ retinae, kainate depolarization of horizontal cells failed to inhibit high $\mathrm{K}^{+}$-evoked $\mathrm{Ca}^{2+}$ signals, and NBQX-induced hyperpolarization failed to enhance these signals in photoreceptors, indicating that inhibitory feedback was disrupted because of the inability of horizontal cells to release GABA.

Although the vesicular release of GABA from horizontal cells appears necessary for feedback inhibition onto photoreceptors, there is evidence that the site of action of the GABA is not on photoreceptors directly (Liu et al., 2013). Generally, the evidence for ionotropic GABA receptors on mammalian photoreceptors has been at best equivocal
(Thoreson and Mangel, 2012; Kemmler et al., 2014); whereas, ionotropic GABA receptor currents in mammalian horizontal cells (Blanco et al., 1996; Wässle et al., 1998; Feigenspan and Weiler, 2004; Liu et al., 2013) have been demonstrated. Depolarization of horizontal cells was shown to inhibit photoreceptor calcium signals in rat retinal slices (Liu et al., 2013). Since antagonists of GABA $A_{A} R$ blocked this action, it was inferred that an autocrine action mediated by GABA release, acting at $G A B A_{A} R s$ on the horizontal cells, was responsible. Since $\mathrm{GABA}_{A}$ receptors possess a relatively high permeability for $\mathrm{HCO}_{3}^{-}$(Bormann et al., 1987), the resulting flux of $\mathrm{HCO}_{3}^{-}$across the horizontal cell membrane during $\mathrm{GABA}_{\mathrm{A}} \mathrm{R}$ activation can change the $\mathrm{pH}$ in the synaptic cleft between the horizontal cell and photoreceptor axon terminal, where it is known that changes of $\mathrm{pH}$ in the cleft modulate the gating of photoreceptor Ca channels (Hirasawa and Kaneko, 2003; Vessey et al., 2005; Cadetti and Thoreson, 2006; Davenport et al., 2008), which leads to altered glutamate release (Barnes et al., 1993). The model unites the vesicular GABA release mechanism in mammals, established in this work, with the more widely accepted $\mathrm{pH}$-sensitive effect (Thoreson and Mangel, 2012).

\section{References}

Babai N, Thoreson WB (2009) Horizontal cell feedback regulates calcium currents and intracellular calcium levels in rod photoreceptors of salamander and mouse retina. J Physiol 587:23532364. CrossRef Medline

Barnes S, Merchant V, Mahmud F (1993) Modulation of transmission gain by protons at the photoreceptor output synapse. Proc Nat Acad Sci U S A 90:10081-10085. Medline

Blanco R, Vaquero CF, de la Villa P (1996) The effects of GABA and glycine on horizontal cells of the rabbit retina. Vis Res 36:39873995 Medline

Bormann J, Hamill OP, Sakmann B (1987) Mechanism of anion permeation through channels gated by glycine and $\gamma$-aminobutyric acid in mouse cultured spinal neurones. J Physiol 385:243-286. Medline

Cadetti L, Thoreson WB (2006) Feedback effects of horizontal cell membrane potential on cone calcium currents studied with simultaneous recordings. J Neurophysiol 95:1992-1995. CrossRef Medline

Ciolofan C, Lynn BD, Wellershaus K, Willecke K, Nagy JI (2007) Spatial relationships of connexin36, connexin57 and zonula occludens -1 in the outer plexiform of mouse retina. Neuroscience 148:473-488. CrossRef Medline

Cueva JG, Haverkamp S, Reimer RJ, Edwards R, Wässle H, Brecha NC (2002) Vesicular gamma-aminobutyric acid transporter expression in amacrine and horizontal cells. J Comp Neurol 445:227-237. Medline

Davenport CM, Detwiler PB, Dacey DM (2008) Effects of pH buffering on horizontal and ganglion cell light responses in primate retina: evidence for the proton hypothesis of surround formation. J Neurosci 28:456-464. CrossRef Medline

Dedek K, Pandarinath C, Alam NM, Wellershaus K, Schubert T, Willecke K, Prusky GT, Weiler R, Nirenberg S (2008) Ganglion cell adaptability: does the coupling of horizontal cells play a role? PLoS One 3:e1714. doi: 10.1371/journal.pone.0001714. CrossRef Medline

Dedek K, Breuninger T, Pérez de Sevilla Müller L, Maxeiner S, Schultz K, Janssen-Bienhold $U$, Willecke K, Euler T, Weiler $R$ (2009) A novel type of interplexiform amacrine cell in the mouse retina. Eur J Neurosci 30:217-228. CrossRef Medline

Dorgau B, Herrling R, Schultz K, Greb H, Segelken J, Ströh S, Bolte P, Weiler R, Dedek K, Janssen-Bienhold U (2015) Connexin50 
couples axon terminals of mouse horizontal cells by homotypic gap junctions. J Comp Neurol 523:2062-2081. CrossRef Medline Fahrenfort I, Steijaert M, Sjoerdsma T, Vickers E, Ripps H, van Asselt J, Endeman D, Klooster J, Numan R, ten Eikelder H, von Gersdorff $\mathrm{H}$, Kamermans M (2009) Hemichannel-mediated and pH-based feedback from horizontal cells to cones in the vertebrate retina. PLoS One 4:e6090. CrossRef Medline

Farley FW, Soriano P, Steffen LS, Dymecki SM (2000) Widespread recombinase expression using FLPeR (flipper) mice. Genesis 28: 106-110. Medline

Feigenspan A, Weiler R (2004) Electrophysiological properties of mouse horizontal cell GABAA receptors. J Neurophysiol 92:27892801. CrossRef Medline

Feigenspan A, Trümpler J, Dirks P, Weiler R (2009) Ether-à-gogorelated gene (erg1) potassium channels shape the dark response of horizontal cells in the mammalian retina. Pflugers Arch 458:35977. CrossRef Medline

Guo C, Stella SL Jr, Hirano AA, Brecha NC (2009) Plasmalemmal and vesicular gamma-aminobutyric acid transporter expression in the developing mouse retina. J Comp Neurol 512:6-26. CrossRef Medline

Guo C, Hirano AA, Stella SL Jr, Bitzer M, Brecha NC (2010) Guinea pig horizontal cells express GABA, the GABA-synthesizing enzyme GAD 65, and the GABA vesicular transporter. J Comp Neurol 518:1647-1669. CrossRef Medline

Haverkamp S, Wässle H (2000) Immunocytochemical analysis of the mouse retina. J Comp Neurol 424:1-23. Medline

Haverkamp S, Grünert U, Wässle H (2000) The cone pedicle, a complex synapse in the retina. Neuron 27:85-95. Medline

Hirano AA, Brandstätter JH, Brecha NC (2005) Cellular distribution and subcellular localization of molecular components of vesicular transmitter release in horizontal cells of rabbit retina. J Comp Neurol 488:70-81. CrossRef Medline

Hirano AA, Brandstätter JH, Vila A, Brecha NC (2007) Robust syntaxin-4 immunoreactivity in mammalian horizontal cell processes. Vis Neurosci 24:489-502. CrossRef Medline

Hirano AA, Brandstätter JH, Morgans CW, Brecha NC (2011) SNAP25 expression in mammalian retinal horizontal cells. J Comp Neurol 519:972-988. CrossRef Medline

Hirasawa H, Kaneko A (2003) $\mathrm{pH}$ changes in the invaginating synaptic cleft mediate feedback from horizontal cells to cone photoreceptors by modulating Ca2 + channels. J Gen Physiol 122:657671. CrossRef Medline

Hombach S, Janssen-Bienhold U, Söhl G, Schubert T, Büssow H, Ott T, Weiler R, Willecke K (2004) Functional expression of connexin57 in horizontal cells of the mouse retina. Eur $\mathrm{J}$ Neurosci 19:2633-2640. CrossRef Medline

Honoré T, Davies SN, Drejer J, Fletcher EJ, Jacobsen P, Lodge D, Nielsen FE (1988) Quinoxalinediones: potent competitive nonNMDA glutamate receptor antagonists. Science 241:701-703. Medline

Huettner JE (1990) Glutamate receptor channels in rat DRG neurons: activation by kainate and quisqualate and blockade of desensitization by Con A. Neuron 5:255-266. Medline

Janssen-Bienhold U, Trümpler J, Hilgen G, Schultz K, Müller LP, Sonntag S, Dedek K, Dirks P, Willecke K, Weiler R (2009) Connexin57 is expressed in dendro-dendritic and axo-axonal gap junctions of mouse horizontal cells and its distribution is modulated by light. J Comp Neurol 513:363-374. CrossRef

Jellali A, Stussi-Garaud C, Gasnier B, Rendon A, Sahel JA, Dreyfus $\mathrm{H}$, Picaud S (2002) Cellular localization of the vesicular inhibitory amino acid transporter in the mouse and human retina. $\mathrm{J}$ Comp Neurol 449:76-87. CrossRef Medline

Jeon CJ, Strettoi E, Masland RH (1998) The major cell populations of the mouse retina. J Neurosci 18:8936-8946. Medline

Johnson J, Chen TK, Rickman DW, Evans C, Brecha NC (1996) Multiple gamma-aminobutyric acid plasma membrane transporters (GAT-1, GAT-2, GAT-3) in the rat retina. J Comp Neurol 375:212-224. CrossRef Medline
Johnson J, Tian N, Caywood MS, Reimer RJ, Edwards RH, Copenhagen DR (2003) Vesicular neurotransmitter transporter expression in developing postnatal rodent retina: GABA and glycine precede glutamate. J Neurosci 23:518-529. Medline

Kemmler R, Schultz K, Dedek K, Euler T, Schubert T (2014) Differential regulation of cone calcium signals by different horizontal cell feedback mechanisms in the mouse retina. J Neurosci 34:1182611843. CrossRef Medline

Lee H, Brecha NC (2010). Immunocytochemical evidence for SNARE protein-dependent transmitter release from guinea pig horizontal cells. Eur J Neurosci 31:1388-1401. CrossRef Medline

Liu X, Hirano AA, Sun X, Brecha NC, Barnes S (2013) Calcium channels in rat horizontal cells regulate feedback inhibition of photoreceptors through an unconventional GABA- and $\mathrm{pH}-$ sensitive mechanism. J Physiol 591:3309-3324. CrossRef

Madisen L, Zwingman TA, Sunkin SM, Oh SW, Zariwala HA, Gu H, Ng LL, Palmiter RD, Hawrylycz MJ, Jones AR, Zeng H (2010) A robust and high-throughput Cre reporting and characterization system for the whole mouse brain. Nat Neurosci 13:133-140. CrossRef Medline

Mclntire SL, Reimer RJ, Schuske K, Edwards RH, Jorgensen EM (1997) Identification and characterization of the vesicular GABA transporter. Nature 389:870-876. CrossRef

McMahon MJ, Packer OS, Dacey DM (2004) The classical receptive field surround of primate parasol ganglion cells is mediated primarily by a non-GABAergic pathway. J Neurosci 24:3736-3745. CrossRef Medline

Patneau DK, Mayer ML (1991) Kinetic analysis of interactions between kainate and AMPA: evidence for activation of a single receptor in mouse hippocampal neurons. Neuron 6:785-798. Medline

Pattnaik B, Jellali A, Sahel J, Dreyfus H, Picaud S (2000) GABAC receptors are localized with microtubule-associated protein $1 \mathrm{~B}$ in mammalian cone photoreceptors. J Neurosci 20:5789-5796.

Peichl L, González-Soriano J (1994) Morphological types of horizontal cell in rodent retinae: a comparison of rat, mouse, gerbil and guinea pig. Vis Neurosci 11:501-517. Medline

Röhrenbeck J, Wässle H, Heizmann CW (1987) Immunocytochemical labelling of horizontal cells in mammalian retina using antibodies against calcium-binding proteins. Neurosci Lett 77:255-260. Medline

Sauer B (1998) Inducible gene targeting in mice using the Cre/lox system. Methods 14:381-392. CrossRef Medline

Schwartz EA (2002) Transport-mediated synapses in the retina. Physiol Rev 82:875-891. CrossRef Medline

Schubert T, Weiler R, Feigenspan A (2006) Intracellular calcium is regulated by different pathways in horizontal cells of the mouse retina. J Neurophysiol 96:1278-1292. CrossRef Medline

Shelley J, Dedek K, Schubert T, Feigenspan A, Schultz K, Hombach S, Willecke K, Weiler R (2006) Horizontal cell receptive fields are reduced in connexin57-deficient mice. Eur J Neurosci 23:31763186. CrossRef Medline

Sherry DM, Mitchell R, Standifer KM, Du Plessis B (2006) Distribution of plasma membrane-associated syntaxins 1 through 4 indicates distinct trafficking functions in the synaptic layers of the mouse retina. BMC Neurosci 7:54. CrossRef Medline

Shimshek DR, Kim J, Hübner MR, Spergel DJ, Buchholz F, Casanova E, Stewart AF, Seeburg PH, Sprengel R (2002) Codon-improved Cre recombinase (iCre) expression in the mouse. Genesis 32:1926. Medline

Ströh S, Sonntag S, Janssen-Bienhold U, Schultz K, Cimiotti K Weiler R, Willecke K, Dedek K (2013) Cell-specific cre recombinase expression allows selective ablation of glutamate receptors from mouse horizontal cells. PLoS One 8(12):e83076. doi:10.1371/ journal.pone.0083076. CrossRef Medline

Tachibana M (1983) lonic currents of solitary horizontal cells isolated from goldfish retina. J Physiol 345:329-51. Medline

Tatsukawa T, Hirasawa H, Kaneko A, Kaneda M (2005) GABAmediated component in the feedback response of turtle retinal cones. Vis Neurosci 22:317-324. CrossRef Medline 
Thoreson WB, Burkhardt DA (1990) Effects of synaptic blocking agents on the depolarizing responses of turtle cones evoked by surround illumination. Vis Neurosci 5:571-583. Medline

Thoreson WB, Mangel SC (2012) Lateral interactions in the outer retina. Prog Retin Eye Res 31:407-441. CrossRef Medline

Thoreson WB, Babai N, Bartoletti TM (2008). Feedback from horizontal cells to rod photoreceptors in vertebrate retina. J Neurosci 28:5691-5695. CrossRef Medline

Tong Q, Ye CP, Jones JE, Elmquist JK, Lowell BB (2008) Synaptic release of GABA by AgRP neurons is required for normal regulation of energy balance. Nat Neurosci 11:998-1000. CrossRef Medline

Verweij J, Hornstein EP, Schnapf JL (2003) Surround antagonism in macaque cone photoreceptors. J Neurosci 23:10249-10257. Medline

Vessey JP, Stratis AK, Daniels BA, Da Silva N, Jonz MG, Lalonde MR, Baldridge WH, Barnes S (2005) Proton-mediated feedback inhibition of presynaptic calcium channels at the cone photoreceptor synapse. J Neurosci 25:4108-4117. CrossRef Medline

Wang TM, Holzhausen LC, Kramer RH (2014) Imaging and optogenetic $\mathrm{pH}$ sensor reveals that protons mediate lateral inhibition in the retina. Nat Neurosci 17:262-268. CrossRef Medline

Wässle H (2004) Parallel processing in the mammalian retina. Nat Rev Neurosci 5:747-757. CrossRef Medline

Wässle H, Koulen P, Brandstätter JH, Fletcher EL, Becker CM (1998) Glycine and GABA receptors in the mammalian retina. Vision Res 38:1411-1430. Medline

Wässle H, Puller C, Müller F, Haverkamp S (2009) Cone contacts, mosaics, and territories of bipolar cells in the mouse retina. J Neurosci 29:106-117 CrossRef Medline

Witkovsky P, Gábriel R, Križaj D (2008) Anatomical and neurochemical characterization of dopaminergic interplexiform processes in mouse and rat retinas. J Comp Neurol 510:158-174. CrossRef Medline 